\title{
Identifying the Challenges in Commercializing High Technology: A Case Study of Quantum Key Distribution Technology
}

\author{
Anas Al Natsheh, Saheed A. Gbadegeshin, Antti Rimpiläinen, \\ Irna Imamovic-Tokalic, and Andrea Zambrano
}

\author{
"It is time for us all to stand and cheer for the doer, the") \\ achiever - the one who recognizes the challenges and does \\ something about it.
}

Vince Lombardi (1913-1970)

Player, coach, and executive of American Football

\begin{abstract}
This article examines the challenges in commercializing high technologies successfully and sustainably using quantum key distribution (QKD) technology as a case study. Quantum communication is increasingly relevant to cybersecurity and nanotechnology, which will replace current technologies and change the way we live. To understand how such high technology could be successfully commercialized, we interviewed individuals from four metrology institutions and two international companies. The result revealed that scattered and small markets, supply chain development, technology validation/certification, a lack of available or adequate infrastructure, and after-sales services are the most serious challenges facing successful commercialization of quantum communication technology. To validate these challenges, we conducted a survey of 60 experts, 49 of whom agreed that above-mentioned factors could affect the commercialization success of QKD technology. Likewise, the survey revealed that technical development, customer orientation/awareness, and government regulations could also hinder the commercialization of QKD technology.
\end{abstract}

\section{Introduction}

One of the key drivers for economic growth nowadays is knowledge, and it involves high investment in education and training, research and development (R\&D), and relationships between governments, academia, and industry (Lowe, 2005). To realize the benefits of knowledge and to receive returns from these investments, the resulting innovations or inventions must be sold, or commercialized (Meyers, 2009). Indeed, commercialization is an important contributor to economic growth (Tahvanainen \& Nikulainen, 2011), and it makes technology available to end users. In essence, commercialization is an exchange of know-how for money (Speser, 2008), but it can be perceived in different ways, including:
- a series of activities for converting an invention to a product or service (Rosa \& Rose, 2007)

- the process of taking the $R \& D$ of an organization to an industry (Cornford, 2002)

- the identification of a business opportunity for a certain scientific or engineering invention and subsequent steps to design, develop, and manufacture the invention to make it useful (Michael, 1990)

- the adoption of a new technology or service by customers (Tanev \& Frederiksen, 2014)

- any scheme that permits members of a technological innovation team to receive economic gains from their 


\title{
Identifying the Challenges in Commercializing High Technology
}

\author{
Anas Al Natsheh, Saheed A. Gbadegeshin, Antti Rimpiläinen, Irna Imamovic-Tokalic, and Andrea Zambrano
}

efforts, including through patent licensing, research grants, and R\&D joint ventures (Kalaitzandonakes, 1997)

Here, we focus on the definition of Pellikka and Malinen (2011) who state that commercialization brings high-technology innovations to the market and makes innovative products benefit of society. Commercialization is not a straightforward process; many challenges must be overcome. Although previous studies have outlined some challenges, this study also attempts to fill the perceived gap by identifying additional challenges of commercialization, particularly for high technologies. Usually, new technologies face many problems in the beginning of their lifecycle because they are new to the end users and they lack standardization or third-party certification. In this study, we examine quantum key distribution (QKD) technology as a case study because is a new high technology of increasing importance within the domain of cybersecurity.

QKD is a mean of sending and receiving safe information; it uses cryptographic keys to encode information at the point of dispatching and the keys are used by the receiver to decode or retrieve the information. Presently, QKD kits are commercially available but there are no any independent measurements and standards in the industry. Due to cybersecurity pressures, the European Union has funded a project named "Metrology for Industrial Quantum Communications" (MIQC). The MIQC project aims to develop and commercialize standards for the QKD technology systems. Most of the leading metrology centers in Europe participated in the development of new QKD standards and certification. However, in this article, we present the findings of the commercialization study, which examined how the new QKD technology would be available in the market. Although the case study focuses on QKD technology, the main motive for sharing the findings is that we believe that the study has broader implications and value for assisting researchers and innovators/inventors in many high-technology fields; the findings may help them become aware of and overcome hidden commercialization challenges.

This article is structured as follows. First, we review the literature on the challenges of commercializing high technology. Next, we describe the interview and survey methodology used in our QKD case study and then we present the results. Finally, we discuss the key findings and provide conclusions.

\section{Literature Review: Commercializing High Technology}

For a high-technology innovation to successfully reach the market, a company's commercialization team must identify, obtain, combine, and manage needed technological knowledge. The innovation must be developed into a product, which must then be manufactured, marketed, and distributed. Ongoing success with subsequent commercialization attempts can be facilitated by a growth strategy that exploits economies of joint costs and scale. Furthermore, an innovation can be successful if the innovation team or company can adhere to their learning paths and create and maintain a good network (Chandler, 2005). Additionally, the team must not only concentrate on a niche market but also focus on a wider (potential) market because a niche market may not be able to sustain the product in long run (Slater \& Mohr, 2006).

Likewise, to successfully commercialize high technology, it is necessary to follow a market-oriented process: one that starts with market, ends with the market, and involves the market throughout the entire process (Valiauga, 2013). Nichols (2013) adds that commercialization is supposed to be a well-planned and well-implemented activity that improves product performance relative to its price and that focuses on competitors. Fletcher and Bourne (2012) state that there are 10 simple rules for successful commercialization: i) science must be differentiated from business; ii) know that there is no one specific way to commercialize; iii) know the company's rights and the rights of its partners, iv) consider the of implications of private and public business; v) decide what the company wants to give; vi) be realistic; vii) accept that a market may not exist in the beginning; viii) consider the difference between wants and needs; ix) make the invention comprehensive; and $\mathrm{x}$ ) customers are the ultimate peer reviewers.

Pellikka and colleagues (2012) argue that the main difficulties of the commercialization process relate to marketing, resources, the business environment, and the planning and management of commercialization process. The marketing challenges relate to a failure to obtain sufficient and relevant market information, a failure to use it properly, insufficient knowledge about the international market and the business growth, and an inability to establish both local and international sales and distributions. These scholars explain further that the resource challenges of the commercialization process are an inability to acquire and assign resources, 


\title{
Identifying the Challenges in Commercializing High Technology
}

\author{
Anas Al Natsheh, Saheed A. Gbadegeshin, Antti Rimpiläinen, Irna Imamovic-Tokalic, and Andrea Zambrano
}

inadequate managerial and business skills, and insufficient funds to market the new product. In the business environment, they identify additional commercialization challenges, including a lack of available or adequate business infrastructure, low market potential, and insufficient business partners. Lastly, these authors mention that lack of a systematic model, time and materials for getting public funds, and insufficient knowhow threaten the planning and management of a commercialization process. However, these problems can be overcome through the effective pre-planning activities, better utilization of resources, and internal commercialization training of key staff.

Epting, Gatling, and Zimmer (2011) highlight common challenges with financing, production, distributing and marketing. The authors explain further that many innovators face the following problems in their commercialization adventures:

1. Undue delay caused by the inventor's attempts to "perfect" their product may allow a competitive, lower-quality product to enter the market, to the detriment of the inventor.

2. Licensing manufacturing to another company may hasten market entry, but at the expense of the inventor's control.

\section{Funding may be exhausted in pre-sales activities.}

4. Distribution and supply chains take time and expertise to establish.

In addition, Parker and Mainelli (2001) identify frequent mistakes made during technology commercialization, including: i) assuming that new features will be beneficial, ii) using top-down market analysis, iii) insufficient testing of the technology, iv) failure to assign a specific person or team to oversee the commercialization process, and v) an inability to value the new technology fully. Rosa and Rose (2007) add that financial problems due to insufficient funds to complete commercialization and human resource problems in the form of a lack of skilful people to sell and promote the innovating products are key obstacles facing technology commercialization.

Tahvanainen and Nikulainen (2011) found that a lack of time and interest, a negative attitude in the research environment, economic risks, conflicts of interest, bureaucratic disturbance, lack of business or commercialization knowledge, incompatibility of commercialization with the ethics of science, and issues with ownership rights are challenges confronting commercialization. Similarly, Bulsara, Gandhi, and Porey (2010) outline difficulties with patent filing processes, commercialization interests, commercialization option selection, commercialization supports, obsolescence of technology, educational and business background of innovator, and the general business environment.

The above scholars hold a wide range of views regarding the challenges of commercialization. Others have identified specific challenges in particular industries. For instance, in focusing on commercialization biopharmaceutical knowledge in Iran, Nassiri-Koopaei and colleagues (2014) outline three main obstacles to commercialization in that country and industry: i) policy, ii) regulations, and iii) management. Likewise, Szuhaj and McCullough (2009) argue that supply chain management in the bio-pharmaceutical industry is a particularly critical aspect of commercialization in that industry.

Kaarela (2013), focusing on the nanotechnology, explains that the main processes of commercialization process are market validation in the planning phase and multidisciplinary team and mainstream customers in the execution phase. Although the author focuses on 64 cases in the Finnish-Russian nanotechnology commercialization alliance, he presents many problems associated with the technology commercialization. He notes that most of these challenges come from the business side rather than technology side. He also presents three main challenges: i) understanding the customer needs, ii) describing the business benefits not the technology benefits, and iii) complementing the team's skill with the right partner. In the same view, McNeil and colleagues (2007) list, in their final report for the Technology Administration agency of the United States Department of Commerce, the following barriers to commercialization in the nanotechnology industry: i) the ten-year cycle time from scientific results in a laboratory to a commercial product; ii) the difference between researchers and applied scientists; iii) the difference in funding between basic research and applied research; iv) a lack of understanding that for every dollar invested in basic research almost $\$ 100$ is required for a commercially viable product; v) long timescales needed for patenting; vi) uncertainty of potential regulations, and vii) the high risk of new scientific results. In addition, Pfautsch (2007) identifies the main barriers to commercialization efforts with carbon nanotube composites: i) the high cost of equipment, ii) a lack of knowledge about environment health and safety, iii) a lack of 


\section{Identifying the Challenges in Commercializing High Technology}

\section{Anas Al Natsheh, Saheed A. Gbadegeshin, Antti Rimpiläinen, Irna Imamovic-Tokalic, and Andrea Zambrano}

a risk assessment or lifecycle assessment, iv) a lack of standards, v) a need for properly trained workers, and vi) cross-patenting.

Boehlje (2004) analyzed previous work on commercialization of agricultural technologies and found common challenges that included gaining customer/consumer acceptance, capital market accessibility, value capture/sharing, protecting intellectual property, and selecting innovation strategies.

In the health sector, Booz Allen Hamilton and three other organizations in the United States (2012) confirmed that the problems facing new invention commercialization are access to capital, potential limitations of traditional technology transfer, the need for entrepreneurial skills, and the difficulty of navigating the complexities of the healthcare market. Additionally, Scanlon and Lieberman (2007) analyzed historical medical breakthroughs and found that the two major challenges of commercialization in the medical field are the ability of the academic community to change the culture of the scientists to commercialize their technology and the ability of the business community to communicate successfully with the scientists.

Furthermore, O'Brien and colleagues (2004) investigated barriers to the deployment of integrated gasification combined cycle (IGCC) technology, the most successful method of producing electric power utilizing coal gasification in the US electric industry. They found that the most substantial barriers were financial, environmental, cultural, and legal. The financial barrier consisted of tax issues, credit concerns, project finance, market for emissions credits, licensing fees, and cost of operation. The environmental barrier included emission limitation, environmental permitting processes, and uncertain environmental rules and enforcement. The cultural barriers were regulator viewpoints, public perception, corporate culture of plant developers, past failures, and difficulties of IGCC plants. And, the legal barrier included plant-siting procedures, standard market design, electric industry restructuring, and uncertainty over regulatory treatment.

Although the above-mentioned scholars investigated the same topic in different fields, their findings are summarized in Table 1.

Notably, Table 1 highlights that market- and fundingrelated issues are the most common challenges in all aforementioned sectors. Our recent research (Al Natsheh et al., 2015) also revealed that the following factors need to be considered during technology commercialization:

- novelty and clear added value

- technology functionality

- a non-complicated first set of products

- product certification/accreditation

- the right team

- sufficient capital

- a good business model

- a proper manufacturing plan

- ongoing updates and product maintenance

Although our recent work focused on university technology transfer, these findings may be applicable to the commercialization of any technology. To reach the source of problems facing the commercialization of high technology, we conducted the present study using QKD technology as a case study. Our goal for the QKD study was to understand how the technology could be successfully commercialized. Before presenting the results, the next section describes our research methodology.

\section{Methodology}

To maximize the efficiency and methodological self-consistency of the qualitative method, we followed the guidelines stated by Creswell (2009) and Yin (1994). We used a qualitative research method featuring six interviews with innovators (4) from metrology institutions and individuals from companies (2) engaging in QKD technology, and a survey of stakeholders. Our primary research question was:

What are the challenges that can hinder successful commercialization of QKD technology?

Based on our experience in QKD research projects and other high-technology commercialization projects, we identified five possible challenges that could hinder successful commercialization of QKD technology. They are:

\section{Market size}

2. Possibility of building the supply chain

3. Availability of technology validation/certification

4. Availability of infrastructure for the new technology

5. Possibility of offering after sales-sales services (especially product update and maintenance) 


\section{Identifying the Challenges in Commercializing High Technology}

\section{Anas Al Natsheh, Saheed A. Gbadegeshin, Antti Rimpiläinen, Irna Imamovic-Tokalic, and Andrea Zambrano}

Table 1. Summary of commercialization challenges

\begin{tabular}{lll}
\hline Study & Challenges & Application \\
\hline Pellikka et al. (2012) & $\begin{array}{l}\text { Marketing, resources, business environment, and planning and management of } \\
\text { commercialization process }\end{array}$ & General \\
\hline
\end{tabular}

Tahvanainen \&

Nikulainen (2011)
Lack of time, lack of interest, negative attitude of research environment, economic risks, General conflicts of interest, bureaucratic disturbance, lack of business or commercialization knowledge, incompatibility of commercialization with the ethics of science, and ownership right problem

\begin{tabular}{|c|c|c|}
\hline Chiesa \& Frattini (2011) & Volatility, interconnectedness, and proliferation of new technologies to fit the market & General \\
\hline Bulsara et al. (2010) & $\begin{array}{l}\text { Patent filing processes, commercialization interest, selecting of commercialization } \\
\text { options, commercialization supports, obsolescence of technology, educational and } \\
\text { business background of innovator, and general business environment }\end{array}$ & General \\
\hline Epting et al. (2011) & $\begin{array}{l}\text { Inventor's procrastination for making a perfect product, licensing issues, insufficient } \\
\text { funds, and insufficient time and expertise to establish distribution and supply chains }\end{array}$ & General \\
\hline Rosa \& Rose (2007) & Financial problems and human resource problems & General \\
\hline Parker \& Mainelli (2001) & $\begin{array}{l}\text { Innovators' assumption, top-down market analysis, insufficient test of the technology, } \\
\text { failure to assign specific person or team to oversee commercialization process and } \\
\text { inability to value the new technology }\end{array}$ & General \\
\hline $\begin{array}{l}\text { Nassiri-Koopaei et al. } \\
\text { (2014) }\end{array}$ & Policy, regulations, and management & Bio-pharmaceutical \\
\hline $\begin{array}{l}\text { Szuhaj \& McCullough } \\
\text { (2009) }\end{array}$ & Supply chain management & Bio-pharmaceutical \\
\hline Kaarela (2013) & $\begin{array}{l}\text { Not understanding customer needs, describing technology benefits instead of business } \\
\text { benefits, and not complementing team's skill with the right partner }\end{array}$ & Nanotechnology \\
\hline McNeil et al. (2007) & $\begin{array}{l}\text { Ten-year cycle for innovation, the gap between researcher and applied scientists, the gap } \\
\text { in funding between basic research and applied research, lack of understanding that for } \\
\text { every dollar invested in basic research almost } \$ 100 \text { is required for a commercially viable } \\
\text { product, time to patent, uncertainty of potential regulations, and the high risk of new } \\
\text { scientific results }\end{array}$ & Nanotechnology \\
\hline Pfautsch (2007) & $\begin{array}{l}\text { High cost of equipment, lack of knowledge about environment health and safety, lack of } \\
\text { a risk assessment or lifecycle assessment, lack of standards, need for properly trained } \\
\text { workers, and the issue of cross-patenting }\end{array}$ & Nanotechnology \\
\hline Boehlje (2004) & $\begin{array}{l}\text { Gaining customer/consumer acceptance, capital market accessibility, value } \\
\text { capture/sharing, protecting of intellectual property, and selection of innovation strategy }\end{array}$ & Food and Agriculture \\
\hline $\begin{array}{l}\text { Booz Allen Hamilton et } \\
\text { al. (2012) }\end{array}$ & $\begin{array}{l}\text { Access to capital, potential limitations of traditional technology transfer, the need for } \\
\text { entrepreneurial skills, and the difficulty of navigating the complexities of the healthcare } \\
\text { market }\end{array}$ & Health \\
\hline $\begin{array}{l}\text { Scanlon \& Lieberman } \\
(2007)\end{array}$ & $\begin{array}{l}\text { Ability of the academic community to change the scientific culture to commercialize } \\
\text { technology, and the ability of the business community to communicate successfully with } \\
\text { the scientists }\end{array}$ & Health (Medical) \\
\hline O'Brien et al. (2004) & Financial, environmental, cultural, and legal & Electricity \\
\hline
\end{tabular}




\title{
Identifying the Challenges in Commercializing High Technology
}

\author{
Anas Al Natsheh, Saheed A. Gbadegeshin, Antti Rimpiläinen, Irna Imamovic-Tokalic, and Andrea Zambrano
}

\section{Interview methodology}

The interview questions consisted of three parts. The first part focused on the interviewee's background, especially as it related to previous projects. The second part centralized on the commercialization of QKD technology. The last part focused on the interviewee's general opinions on the commercialization of high technology. Several weeks prior to the interviews, we sent the interview questions to the participants so that they would have prior knowledge about our goals of the study. The interviews for innovators were conducted in Italy and Finland. The average duration of their interviews was 1 hour and all interviews were recorded.

The innovators work with metrology institutions in the United Kingdom, Italy, and Finland. Three of them hold $\mathrm{PhD}$ degrees; the fourth holds an MSc degree. Each of them has more than 15 years' experience in the field, and they have participated in several basic and applied research studies. Three of the innovators hold patents; one has developed a few products. At the time of the interviews, they were all working on different innovation projects.

The individuals from the companies are all hold managerial roles. The first participating company was established 10 years ago. It designs and produces single-photon counting avalanche diodes and develops active-quenching integrated circuits. The company has networks in five continents and its products are applied in biomedical, industrial, and astrophysical domains. The second company was founded 11 years ago. Its products provide network encryption and photon counting.

The collected data were analyzed using the method of Miles and Huberman (1994), which includes summarization and extraction of key points. Therefore, we first transcribed the interviews and then summarized them. After that, we pinpointed the main information from the summaries. Thereafter, our qualitative results were derived.

\section{Survey methodology}

As a part of the MIQC project, the commercialization team conducted a survey on the project stakeholders' satisfaction and the team included commercialization questions designed to test the qualitative results from the interviews. In the survey, there were 22 questions but five of them were focused on commercialization.
The answers were in multiple-choice format, but respondents were allowed to state their reason for either agreeing or disagreeing. Our survey questions were:

1. Do you think that the market size of quantum cryptography can affect its commercial implementation?

2. How important is the development of standards and quality assurances related to the commercial QKD system in order to ensure the commercial success of this technology?

3. How important is the development of a metrological infrastructure for characterizing the optical components of QKD systems in relation to the development of standards for the market take-up of the QKD technology?

4. In your opinion, what do you think can hinder commercial implementation of quantum cryptography?

5. An empirical study on the commercial implementation of quantum cryptography revealed that building of supply chain, technology validation/certification, a lack of available or adequate infrastructure, and after-sales services are the most serious challenges facing successful commercialization of quantum cryptography. Do you agree?

The questions aimed to validate our findings because the intended participants of the survey are QKD professionals. Invitations to participate in the MIQC survey were sent to about 100 people who we considered the necessary stakeholders of quantum communication technology in Europe; 60 of these professionals participated in the survey, which was made available online from the 1st and 30th of September, 2014. Table 2 provides an overview of the survey participants.

\section{Analysis}

In this study, we used both qualitative methods (i.e., summarization and extraction of key points from interview data) and quantitative methods (i.e., descriptive statistics from survey data), which allowed the findings to be triangulated. Triangulation combines both qualitative and quantitative research methods to obtain various points of view as well as to validate specific claims; it enables researchers to obtain deep understanding and wide knowledge of a phenomenon (Olsen, 2004; Zawawi, 2007). Our research and triangulation process is summarized in Figure 1. 


\section{Identifying the Challenges in Commercializing High Technology}

\section{Anas Al Natsheh, Saheed A. Gbadegeshin, Antti Rimpiläinen, Irna Imamovic-Tokalic, and Andrea Zambrano}

Table 2. Backgrounds and experience levels of the 60 QKD survey participants

\begin{tabular}{|c|c|c|}
\hline & Categories & $\begin{array}{l}\text { Number of } \\
\text { Participants }\end{array}$ \\
\hline \multirow[t]{6}{*}{ Organization } & $\begin{array}{l}\text { Small and Medium } \\
\text { Enterprise (SME) }\end{array}$ & 9 \\
\hline & $\begin{array}{l}\text { Public Liability Company } \\
\text { (PLC) }\end{array}$ & 1 \\
\hline & University & 24 \\
\hline & $\begin{array}{l}\text { Governmental Research } \\
\text { Institute/Centre }\end{array}$ & 23 \\
\hline & $\begin{array}{l}\text { Private Research } \\
\text { Institute/Centre }\end{array}$ & 2 \\
\hline & Other: Standard Institute & 1 \\
\hline \multirow[t]{5}{*}{ Position } & Student & 6 \\
\hline & Researcher & 35 \\
\hline & Professor & 8 \\
\hline & $\begin{array}{l}\text { Research and development } \\
\text { manager }\end{array}$ & 6 \\
\hline & Senior manager or CEO & 5 \\
\hline \multirow[t]{5}{*}{ Experience Level } & Under 5 years & 13 \\
\hline & $5-10$ years & 22 \\
\hline & 11- 15 years & 14 \\
\hline & $16-20$ years & 9 \\
\hline & Above 20 years & 2 \\
\hline
\end{tabular}

\section{Findings}

Our qualitative data analysis revealed that the critical challenges in commercializing QKD technologies were: i) small market size and distribution channels; ii) building a supply chain; iii) technology validation or certification; iv) a lack of available or adequate infrastructure; and v) after-sales services such as product updates and maintenance. Each of these challenges is briefly described below.

1. Scattered and small market size: Our interviewees said that developing an invention was not as difficult as developing a market, especially for the high-technology products. They stressed that the initial market for a new technology is often small, and it might take several years before a large market could be developed. In view of this challenge, there are other problems relating to profitability and sustainability.

Our study also revealed that the small-market challenge becomes greater if the small market is scattered geographically, particularly because of higher costs for sales and after-sales services.

2. Building of supply chain: Our interviewees pointed out the difficulty of building a supply chain for a new technology. One of reasons they cited was the newness of the technology to both suppliers and consumers. They explained further that the components of the new technology may not actually exist or the existing product may need modifications before they can be used as components; in either case, it can be difficult to find the right suppliers. Similarly, they stressed that finding the right distribution channel may be a serious challenge. They explained that the small market size complicates distribution in terms accessibility to customers. Nonetheless, we found that the most difficult challenge is the identification 


\title{
Identifying the Challenges in Commercializing High Technology
}

\author{
Anas Al Natsheh, Saheed A. Gbadegeshin, Antti Rimpiläinen, Irna Imamovic-Tokalic, and Andrea Zambrano
}

and development of the right supply chain because the new technology might have several application areas that cannot be supported by existing supply chains.

3. Technology validation or certification: Our interviewees re-confirmed one of our findings in the previous studies (Al Natsheh et al., 2015). They said that validation/certification of a new technology is a challenge facing high-technology commercialization. To be certified, a technology must work properly, be of sufficient quality, and be safe to use. However, new technology usually requires new formal testing procedures, which may be expensive and may require several sub-projects. In addition, new standards will prescribe measurements that will most likely require development by the metrology community, given that existing measurements and reference artefacts will not be adequate. Thus, validation/certification appears to be a barrier to high-technology commercialization, because the standards and metrology needed to validate/certify such systems is expensive to develop.

4. Lack of available or adequate infrastructure: Our participants mentioned that, in some cases, there is no infrastructure to support new QKD technology. Three interview subjects quickly cited example of $3 \mathrm{G}$ Internet connectivity for smartphones. These participants illustrated that, if smartphone technology were developed without any Internet connectivity infrastructure to support it; then, consumers would not be able to use smartphones. One of the participants cited the example of cloud computing, which is now leading the new technologies: if cloud computing were not available, the insurgency of mobile phone applications and other related technologies would not be possible. Therefore all interviewees agreed that a lack of available or adequate infrastructure is a key challenge in the commercialization of high technology.

5. After-sales services: Our participants also identified after-sales services as a key challenge facing hightechnology commercialization. They explained that selling high-technology products can be less challenging than providing the necessary services to maintain the technology. To confirm another finding from our earlier work (Al Natsheh et al., 2015), we asked the interviewees about the challenges of updating and maintaining products. All of them agreed that it is an important factor to be considered during the technology commercialization process because it also serves as a bottleneck. In support of above-mentioned challenges, the case study technology (i.e., quantum key distribution) requires metrological infrastructure for optical components of quantum optical communication systems, especially for internal single optical components such as single-photon sources and single-photon detectors. A metrology system is mainly for certification and accreditation purposes. Without such a system, quality assurance is at risk. The system level needs to be validated, but validating/certifying techniques are expensive and only yield returns on investment over the long term due to the currently limited market and time-consuming development. Therefore, the aforementioned challenges are apparently evident in the commercialization of QKD technology.

In addition, our quantitative results show that $85 \%$ of the QKD professionals we surveyed agreed that market size would affect the successful commercialization of the new QKD technology and the development of standards or quality assurance is necessary for the commercial success of such technology. Forty-nine of the survey participants (82\%) agreed that it is essential to have sufficient infrastructure for the new QKD technology in order to make a successful product. Likewise, 49 participants (82\%) confirmed that market size, building a supply chain, technology validation/certification, a lack of available or adequate infrastructure, and aftersales services are the most serious challenges facing successful commercialization of QKD. One of the respondents emphasized that: "Customers perceive no urgent need to switch. That's the only problem."

Furthermore, the survey results also revealed that customer orientation/awareness, technical development, and government regulations could affect the commercialization. The reason why many respondents agreed that customer orientation/awareness could hinder QKD commercialization is that QKD deals with industrial systems in which many end users/final customers may not be aware of its importance in the beginning. Table 3 summarizes the quantitative results.

\section{Discussion and Conclusion}

Tanev and Frederiksen (2014), Kaarela (2013), Pellikka and colleagues (2012), Chiesa and Frattini (2011), Boehlje (2004), and Parker and Mainelli (2001) found that market-related issues were among the challenges facing technology commercialization. In the same view, our study revealed that scattered and small market size is one of the factors hinder successful commercializa- 


\title{
Identifying the Challenges in Commercializing High Technology
}

\author{
Anas Al Natsheh, Saheed A. Gbadegeshin, Antti Rimpiläinen, Irna Imamovic-Tokalic, and Andrea Zambrano
}

Table 3. Summary of survey results

\begin{tabular}{ll}
\hline Research Statement & Research Question \\
\hline $\begin{array}{l}\text { 1. Market size can affect QKD } \\
\text { commercialization }\end{array}$ & $\begin{array}{l}\text { Do you think that the market size of quantum cryptography can } \\
\text { affect its commercial implementation? }\end{array}$ \\
\hline $\begin{array}{l}\text { 2. Development of standards and quality } \\
\text { assurances are important for QKD } \\
\text { commercialization }\end{array}$ & $\begin{array}{l}\text { How important is the development of standards and quality } \\
\text { assurances related to the commercial QKD system in order to ensure } \\
\text { the commercial success of this technology? }\end{array}$ \\
\hline $\begin{array}{l}\text { 3. Development of a metrological } \\
\text { infrastructure }\end{array}$ & $\begin{array}{l}\text { How important is the development of a metrological infrastructure } \\
\text { for characterizing the optical components of QKD systems in relation } \\
\text { to the development of standards for the market take-up of the QKD } \\
\text { technology? }\end{array}$ \\
$\begin{array}{l}\text { 4. Market size, building a supply chain, } \\
\text { technology validation/certification, lack of } \\
\text { available or adequate infrastructure, and } \\
\text { after-sales services are the main challenges. }\end{array}$ & $\begin{array}{l}\text { An empirical study on the commercial implementation of quantum } \\
\text { cryptography identified the most serious challenges facing successful } \\
\text { commercialization of quantum cryptography. Do you agree with the } \\
\text { challenges? }\end{array}$ \\
\hline
\end{tabular}

tion of QKD technology. Commercialization of QKD technology could be problematic because the technology relates to both the military and civilian markets. In particular, the military market is large, highly sensitive, bureaucratic, and structured. Thus, each of these markets needs a different approach. Market penetration and size present challenges for these markets. When a market is scattered geographically, the cost of marketing activities and after-sales services are often high; hence, it becomes a challenge for the manufacturer/entrepreneur/innovator of the high technology to have commercial success. Therefore, we argue that market size is important in the commercialization of high technologies because large investments are often involved in developing the technologies; thus, there are must be sufficient markets for such products.

Furthermore, our findings are also in agreement with Szuhaj and McCullough (2009) and Epting and colleagues (2011) in highlighting the importance of building a supply chain. Likewise, the technology validation/certification challenge is in agreement with Pfautsch (2007) because, in a field where a high degree of precision or accuracy is required, such as nanotechnology and QKD technology, technology validation/certification seems to be important. Therefore, technology validation/certification may hinder successful commercialization of QKD technology. For instance, the certification of the high-technology product can be a barrier, especially when the target customers cannot validate the system by themselves or through a third party. In the case study technology, there is no certification yet, and the technology is crucial especially where cyberse- curity is a priority, such as in financial institutions, securities agencies, and the military. In addition, our study revealed that the lack of available or adequate infrastructure and after sales-services could hinder the successful commercialization of QKD technology. These two factors have not yet been investigated by the previous scholars.

However, this study has limitations due to its focus on particular high-technology domain and its relatively small sample size. Nonetheless, the case study is highly important to societal security and provides a starting point for further research in other sectors and with other technologies. Studies that investigate the new challenges identified here, especially technology validation/certification and lack of available or adequate infrastructure, would be particularly welcome.

In summary, based on previous studies and our new findings, we conclude that technology validation/certification, lack of available or adequate infrastructure, and after-sales services present challenges to the successful commercialization of high technology, at least in the case of QKD. Similarly, we agreed that market size or market-related issues are the challenges in technology commercialization, as previous studies have shown. In the same view, we confirmed that building a supply chain is among the high-technology commercialization challenges. Therefore, we advise the innovators, inventors, technology entrepreneurs, as well governments to consider these challenges so that their investments in research, development, and innovation are more likely to bring the desired returns. 


\title{
Identifying the Challenges in Commercializing High Technology
}

\author{
Anas Al Natsheh, Saheed A. Gbadegeshin, Antti Rimpiläinen, Irna Imamovic-Tokalic, and Andrea Zambrano
}

\section{About the Authors}

Anas Al Natsheh is a Senior Business Advisor at the Centre for Measurement and Information Systems (CEMIS-Oulu) in Oulu, Finland, and he is a Principal Lecturer in Research, Development, and Innovation (RDI) at Kajaani University of Applied Sciences, also in Finland. He is an expert in empirical researches, research valorization, and technology commercialization. He holds a PhD from the University of Kuopio (now the University of Eastern Finland), where his research focused on the applications of nanotechnology.

Saheed Adebayo Gbadegeshin is a Project Researcher at the University of Oulu in Finland, and he is a Project Staff member at Kajaani University of Applied Sciences, also in Finland. He holds an MSc degree in Entrepreneurship from the University of Jyväskylä in Finland. His research interests include technology-based entrepreneurship, technology commercialization, and family-run businesses.

Antti Rimpiläinen is a Project Researcher at the University of Oulu in Finland and a Project Staff member at Kajaani University of Applied Sciences, also in Finland. He holds an MSc degree in Economics and Business Administration from the University of Oulu in Finland. His research interests include technology-based entrepreneurship, technology commercialization, networking, and international business.

Irna Imamovic-Tokalic is a Project Staff member at the Kajaani University of Applied Sciences in Finland. She holds a BSc degree in Macrofinancial Management from the University of Sarajevo, Bosnia. Her research interests include technology commercialization, digital media and marketing, graphic design, and financial management.

Andrea Zambrano is a Project Researcher at the Kajaani University of Applied Sciences in Finland. She holds a master's degree in Financial and Management Accounting from the University of Oulu in Finland, and in International Economics from the University of Antwerp in Belgium. Her research interests include financial management, research cooperation with Latin-American regions, and economic impact studies with focuses on benefitcost analyses, financial analyses, and forecasting.

\section{Acknowledgements}

We gratefully acknowledge funding received from the European Metrology Research Programme (EMRP) for the Metrology for Industrial Quantum Communication (MIQC) project (Contract IND06). The EMRP is jointly funded by participating countries within EURAMET and the European Union. We also thank our colleagues from the University of Oulu and the Kajaani University of Applied Sciences for their support during the project.

\section{References}

Al Natsheh, A., Gbadegeshin, S. A., Rimpiläinen, A., ImamovicTokalic, I., \& Zambrano, A. 2015. Building a Sustainable Start-Up? Factors to Be Considered During the Technology Commercialization Process. Forthcoming in the Journal of Advanced Research in Entrepreneurship and New Venture Creation: http://www.asers.eu/journals/jare_nvc.html

Bulsara, H. P., Gandhi, S., \& Porey, P.D. 2010. Commercialization of Technology Innovations and Patents: Issues and Challenges. AsiaPacific Tech Monitor, 27(6): 12-18

Boehlje, M. 2004. Business Challenges in Commercialization of Agricultural Technology. International Food and Agribusiness Management Review, 7(1): 91-104.

Booz Allen Hamilton, California HealthCare Foundation, Robert Wood Johnson Foundation, \& von Liebig Center for Entrepreneurism and Technology Advancement. 2012. Accelerating Commercialization of Cost-Saving Health Technologies.

Chandler, A. D., Jr. 2005. Commercializing High-Technology Industries. Business History Review, 79(3): 595-604. http://dx.doi.org/10.1017/S0007680500081460

Chiesa, V., \& Frattini, F. 2011. Commercializing Technological Innovation: Learning from Failures in High-Tech Markets. Product Development \& Management Association, 28(4): 437-454. http://dx.doi.org/10.1111/j.1540-5885.2011.00818.x

Cornford, A. B. 2002. Innovation and Commercialization in Atlantic Canada: Research Project - Final Report. Moncton, NB: Atlantic Canada Opportunities Agency (ACOA).

http://publications.gc.ca/pub?id=365765\&sl=0

Creswell, J. W. 2009. Research Design: Qualitative, Quantitative, and Mixed Methods Approaches (3rd ed.). London: Sage Publications, Inc.

Epting, T. Gatling, K., \& Zimmer, J. 2011. What Are the Most Common Obstacles to the Successful Commercialization of Research? SML Perspectives, 2: 9.

Fletcher, A. C., \& Bourne, P. E. 2012. Ten Simple Rules to Commercialize Scientific Research. PLoS Compututational Biology, 8(9): e1002712.

http://dx.doi.org/10.1371/journal.pcbi.1002712 


\section{Identifying the Challenges in Commercializing High Technology}

\section{Anas Al Natsheh, Saheed A. Gbadegeshin, Antti Rimpiläinen, Irna Imamovic-Tokalic, and Andrea Zambrano}

Kalaitzandonakes, N. G. 1997. Commercialization of Research and Technology. Washington, D.C.: U.S. Agency for International Development.

Kaarela, M. 2013. Challenges of Technology Commercialization: Lessons from Finnish-Russian Innovation Alliance on Nanotechnology. Paper presented at the EuroNanoforum 2013 Workshop on Technology Commercialization, June 18-20, 2013, in Dublin, Ireland.

http://www.euronanoforum2013.eu/presentations/presentatinsfrom-workshops/

Lowe, C. R. 2005. Commercialisation and Spin-Out Activities of the Institute of Biotechnology. Journal of Commercial Biotechnology, 11(4): 206-317.

http://dx.doi.org/10.1057/palgrave.jcb.3040131

McNeil, R. D., Lowe, J., Mastroianni, T., Croni, J., \& Ferk, D. 2007. Barriers to Nanotechnology Commercialization: Final Report Prepared for U.S. Department of Commerce Technology Administration. Springfield, IL: The University of Illinois.

Meyers, A. D. 2009. Book Review: Commercialization of Innovative Technologies: Bringing Good Ideas to the Marketplace. Journal of Commercial Biotechnology, 15(4): 374-375.

http://dx.doi.org/10.1057/jcb.2009.18

Michael, N. T. 1990. Commercializing Technology: What the Best Companies Do. Planning Review, 18(6): 20-24.

http://dx.doi.org/10.1108/eb054310

Miles, M. B., \& Huberman, A. M. 1994. Qualitative Data Analysis: An Expanded Sourcebook (2nd ed.). Thousand Oaks, CA: Sage Publications, Inc.

MIQC. 2014. The Project. Metrology for Industrial Quantum Communications. Accessed December 1, 2014: http://projects.npl.co.uk/MIQC/project.html

Nassiri-Koopaei, N., Majdzadeh, R., Kebriaeezadeh, A., Rashidian, A., Yazdi, M. T., Nedjat, S., \& Nikfar, S. 2014. Commercialization of Biopharmaceutical Knowledge in Iran: Challenges and Solutions. DARU Journal of Pharmaceutical Sciences, 22:29.

http://dx.doi.org/10.1186/2008-2231-22-29

Nichols, S. P. 2013. Module 1: An Introduction to Commercialization of Science and Technology. Converting Technology to Wealth Workshop. Austin, TX: IC2 Institute, The University of Texas at Austin. Accessed December 1, 2014:

http://ut.gtrade.or.kr/inc/download.asp?key=5288

O'Brien, J. N., Blau, J., \& Rose, M. 2004. An Analysis of the Institutional Challenges to Commercialization and Deployment of IGCC Technology in the U.S. Electric Industry: Recommended Policy, Regulatory, Executive and Legislative Initiatives. New York, NY: Global Change Associates.

Olsen, W. 2004. Triangulation in Social Research: Qualitative and Quantitative Methods Can Really Be Mixed. In Holborn, M. (Ed.), Developments in Sociology. Ormskirk, UK: Causeway Press.

Parker, K., \& Mainelli, M. 2001. Great Mistakes in Technology Commercialization. Strategic Change, 10(7): 383-390.

http://dx.doi.org/10.1002/jsc.560
Pellikka, J., Kajanus, M., Heinonen, M., \& Eskelinen, T. 2012. Overcoming Challenges in Commercialization Process of Innovation. Paper presented at the XXIII ISPIM Conference in Barcelona, Spain. June 17-20, 2012.

Pellikka, J., \& Malinen, P. 2011. Developing Commercialisation of Innovation in High Technology Industries - Regional Perspective. Paper presented at the 56th International Council for Small Business (ICSB) in Stockholm, Sweden, June 15-18, 2011.

Pfautsch, E. 2007. Challenges in Commercializing Carbon Nanotube Composites. Washington, D.C.: Washington Internships for Students of Engineering (WISE).

Rosa, J., \& Rose, A. 2007. Report on Interviews on the Commercialization of Innovation. Ottawa, CA: Statistics Canada.

Scanlon, K. J., \& Lieberman, M. A. 2007. Commercializing Medical Technology. Cytotechnology, 53(1-3): 107-112. http://dx.doi.org/10.1007/s10616-007-9056-5

Slater, S. F., \& Mohr, J. J. 2006. Successful Development and Commercialization of Technological Innovation: Insights Based on Strategy Type. The Journal of Product Innovation Management, 23(1): 26-33. http://dx.doi.org/10.1111/j.1540-5885.2005.00178.x

Speser, P. 2008. What Every Researcher Needs to Know About Commercialization. Providence, RI: Foresight Science \& Technology Inc.

Szuhaj, M., \& McCullough, P. 2009. Supply Chain Planning and the Commercialization Dead Zone. Deloitte Consulting LLP. Accessed September 16, 2014: http://www.deloitte.com/assets/DcomUnitedStates/Local\%20Assets/Documents/us_lshc_Supply\%20Ch ain\%20as\%20a\%20Blindspot_051209.pdf

Tahvanainen, A., \& Nikulainen, T. 2010. Commercialisation at Finnish Universities: Researchers' Perspectives on the Motives and Challenges of Turning Science into Business. Discussion Paper 1234. Helsinki: The Research Institute of the Finnish Economy.

Tanev, S., \& Frederiksen, M. H. 2014. Generative Innovation Practices, Customer Creativity, and the Adoption of New Technology Products. Technology Innovation Management Review, 4(2): 5-10.

http://timreview.ca/article/763

Valiauga, P. 2013. Commercialization of High-tech Radical Innovations: Case Studies of X-ray Imaging Technologies. Paper presented at the Aalto University School of Science, Finland, May 16, 2013. Accessed December 1, 2014: http://noppa.aalto.fi/noppa/kurssi/tu-22.1500/luennot/TU22_1500_povilas_commercialisation_of_hightech_radical_innovations.pdf

Yin, R. K. 1994. Case Study Research: Design and Methods (2nd ed.). Thousand Oaks, CA: Sage Publications Inc.

Zawawi, D. 2007. Quantative Versus Qualitative Methods in Social Sciences: Bridging the Gap. Universiti Putra Malaysia. Accessed on September 29, 2014: http://psasir.upm.edu.my/809/ 